\title{
FLORA OF TURKEY
}

VOLUME THREE

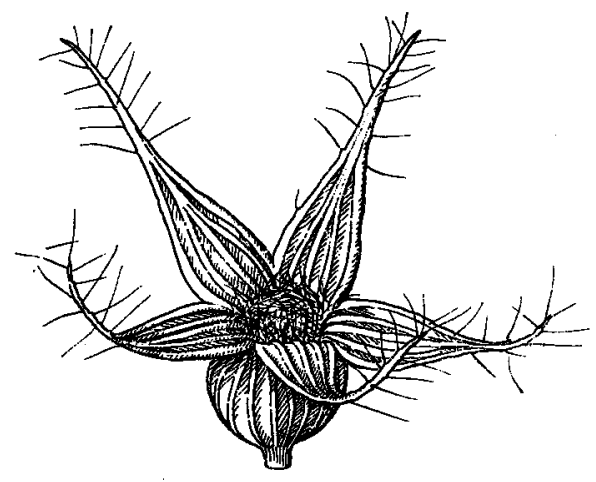





\section{VOLUME THREE}

\section{FLORA OF TURKEY}

and the East Aegean Islands

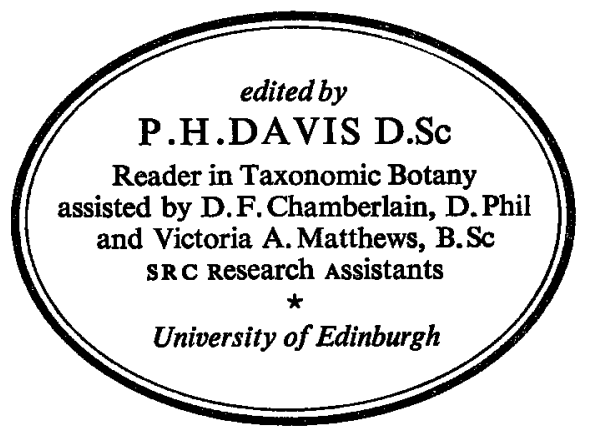

\section{EDINBURGH}

at the UNIVERSITY PRESS 


\section{(C) 1970}

Transferred to Digital Print 2010

\section{Edinburgh University Press}

22 George Square, Edinburgh

Reprinted 1997, 2001, 2008

Printed and bound in Great Britain by CPI Antony Rowe, Chippenham and Eastbourne

A CIP record is available for this book from the British Library

\section{ISBN 0852241542}

